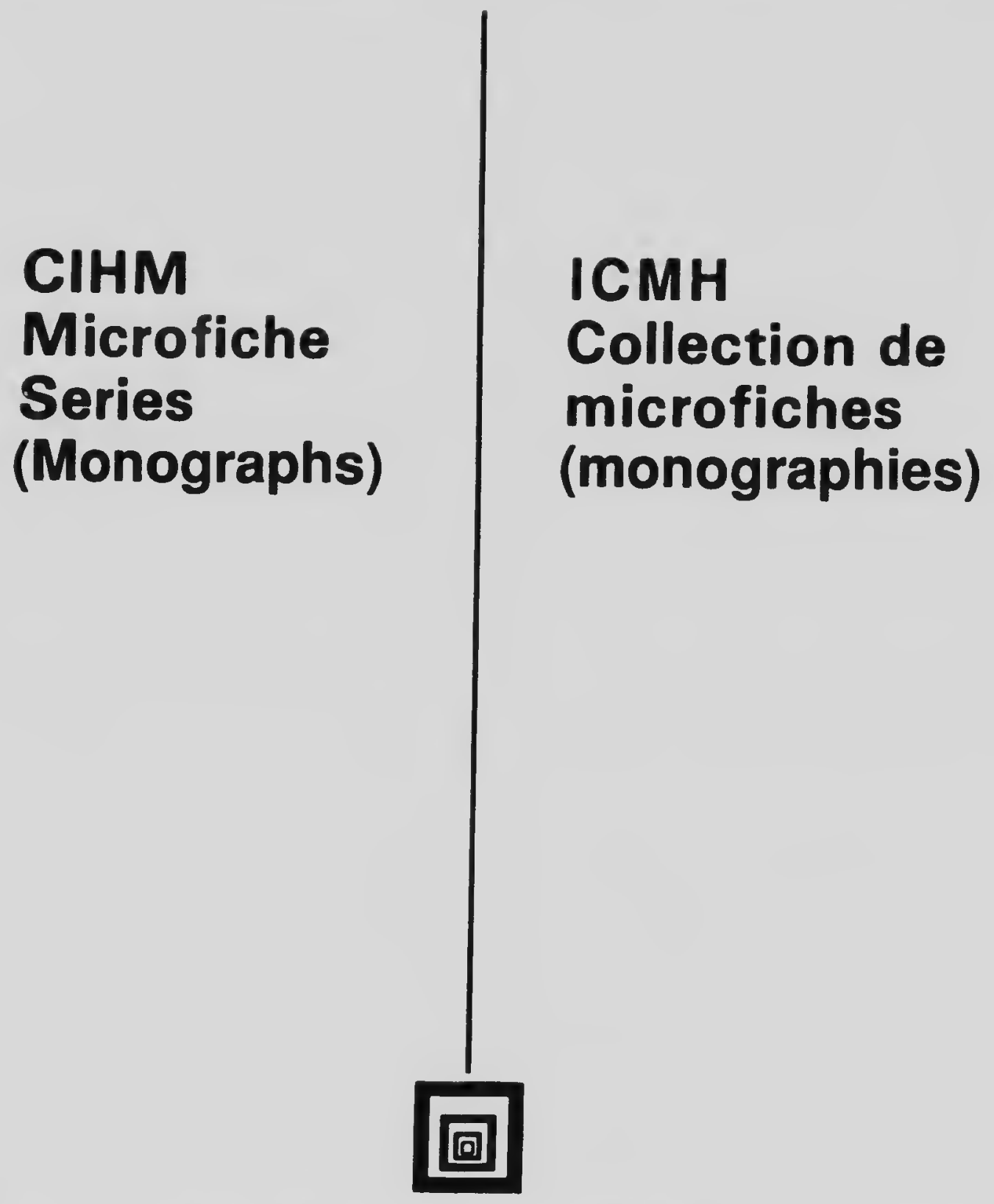

The I

copy

may

the i

signif

check

$\sqrt{1}$

Collection de

microfiches (Monographs) (monographies)
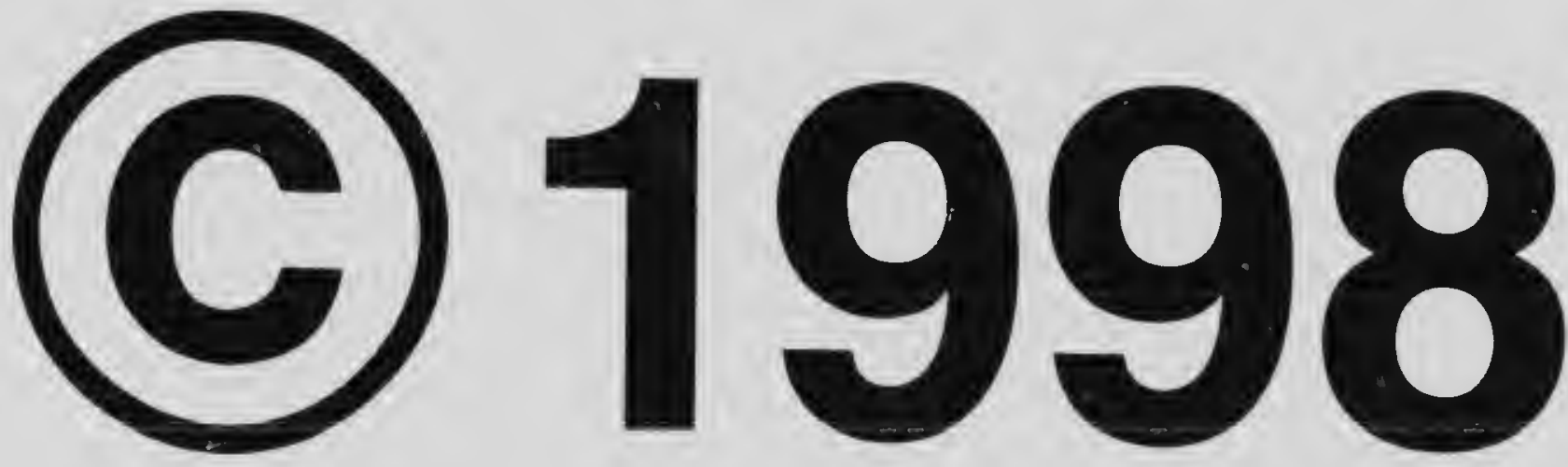

This iter 


\section{Technical and Bil ،ographic Notes / Notes techniques et bibliographiques}

The Institute has attempted to obtain the best original copy available for filming. Features of this copy which may be bibliographically unique, which may alter any of the images in the reproduction, or which may significantly change the usual method of filming are checked below.

\section{Coloured covers /}

Couverture de couleur

\section{Covers damaged /}

Couverture endommagée

Covers restored and/or laminated/

Couverture restaurée etou pelliculée

Cover title missing / Le titre de couverture manque

Coloured maps / Cartes géographiques en couleur

Coloured ink (i.e. other than blue or black)/

Encre de couleur (i.e. autre que bieue ou noire)

Coloured plates and/or illustrations /

Planches etou illustrations en couleur

Bound with other material/

Relié avec d'autres documen's

Only edition available /

Seule édition disponible

Tight binaing may cause shadows or distortion along interior margin / La reliure serrée peut causer de l'ombre ou de la distorsion le long de la marge intérieure.

Blank leaves added during restorations may appear within the text. Whenever possible, these have been omitted from filming / II se peut que certaines pages blanches ajoutées lors d'une restauration apparaissent dans le texte, mais, lorsque cela était possible, ces pages n'ont pas été filmées.

Additional comments /

Commentaires supplémentaires:
L'Institut a microfilmé le rreilleur exemplaire qu'il lui a été possible de se procurer. Les détails de cet exem. plaire qui sont peut-être uniques du point de vue bibliographique, qui peuvent modifier une image reproduite, ou qui peuvent exiger une modification dans la métho. de normale de filmage sont indiqués ci-dessous.

Coloured pages / Pages de couleur

Pages damaged / Pages endommagées

Pages restored and/or laminated /

Pages restaurées etou pelliculées

Pages discoloured, stained or foxed /

Pages décolorées, tachetées ou piquées

\section{Pages detached / Pages détachées}

\section{Showthrough / Transparence}

Quality of print varies /

Qualité inégale de l'impression

Includes supplementary material /

Comprend du matériel supplémentaire

Pages wholly or partially obscured by errata slips, tissues, etc., have been refilmed to ensure the best possible image / Les pages totalement ou partiellement obscurcies par un feuillet d'errata, une pelure, etc., ont été filmées à nouveaus de façon à obtenir la meilleure image possible.

Opposing pages with varying colouration or discolourations are filmed twice to ensure the best possible image / Les pages s'opposant ayant des colorations variables ou des décolorations sont filmées deux fois afin d'obtenir la meilleure image. possible.

This item is filmed at the reduction ratio checked below I

Ce document est filmé au taux de réduction indiqué ci-dessous.

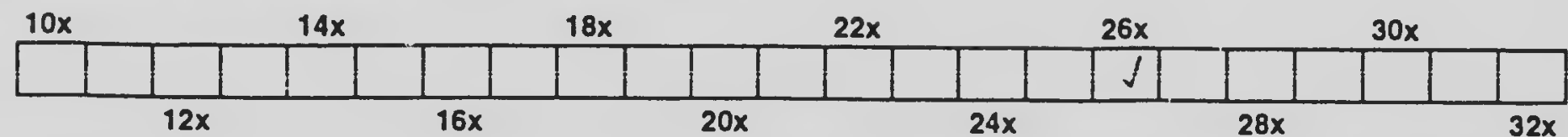


The copy filmed here has been reproduced thanks to the generosity of:

\section{University of Manitoba \\ Elizabeth Dafoe Library \\ winnipeg}

This title was microfilmed with the generous permission of the rights holder:

Edward L. Chambers

The images appearing here are the best quality possible considering the condition and legibility of the original copy and in keeping with the filming contract specifications.

Original copies in printed paper covers are filmed beginning with the front cover and ending on the last page with a printed or illustrated impression, or the back cover when appropriate. All other original copies are filmed beginning on the first page with a printed or illustrated impression, and ending on the last page with a printed or illustrated impression.

The last recorded trame on each microfiche shall contain the symbol $\rightarrow$ (meaning "CONTINUED"), or the symbol $\nabla$ (meaning "END"), whichever applies.

Maps, plates, charts, etc., may be filmed at different reduction ratios. Those too large to be entirely included in one exposure are filmed beginning in the upper left hand corner, left to right and top to bottom, as many frames as required. The following diagrams illustrate the method:

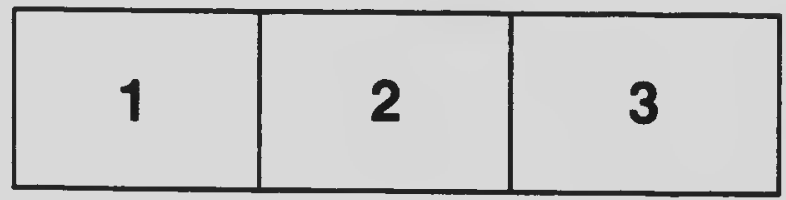

L'exemplaire filmé fut reproduit grâce à la générosité de:

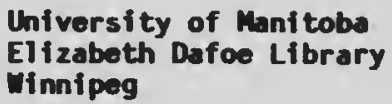

Ce titre a été microfilmé avec l'aimable autorisation du détenteur des droits:

Edward L. Chambers

Les images suivantes ont été reproduites avec le plus grand soin, compte tenu de la condition et de la netteté de l'exemplaire filmé, et en conformité avec les conditions du contrat de filmage.

Les exemplaires originaux dont la couverture en papier est imprimée scnt filmés en commençant par le premier plat et en terminant soit par la dernière page qui comporte une empreinte d'impression ou d'illustration, soit par le second plat, selon le cas. Tous les autres exemplaires originaux sont filmés en commençant par la première page qui comporte une empreinte d'impression ou d'illustration et en terminant par la dernière page qui comporte une telle empreinte.

Un des symboles suivants apparaîtra sur la dernière image de chaque microfiche, selon le cas: le symbole $\rightarrow$ signifie "A SUIVRE", le symbole $\nabla$ signifie "FIN".

Les cartes, planches, tableaux, etc., peuvent être filmés à des taux de réduction différents. Lorsque le document est trop grand pour être reproduit en un seul cliché, il est filmé à partir de l'angle supérieur gauche, de gauche à droite, et de haut en bas, en prenant le nombre d'images nécessaire. Les diagrammes suivants illustrent la méthode.

\begin{tabular}{|l|l|l|}
\hline 1 & 2 & 3 \\
\hline 4 & 5 & 6 \\
\hline
\end{tabular}

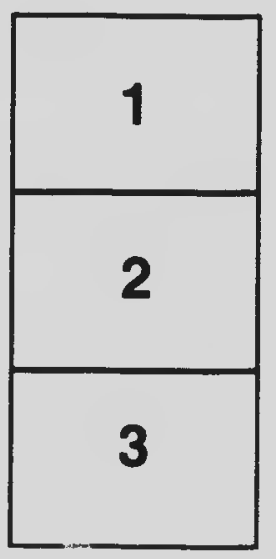


MCROCONY RESOLUIION TEST CHART

(ANSI and ISO TEST CHART No 2)

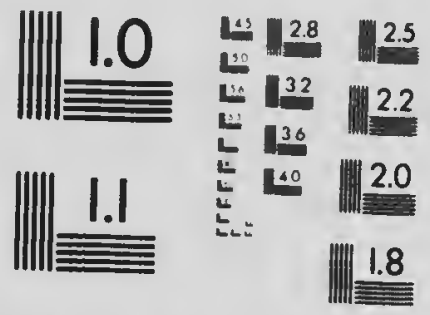

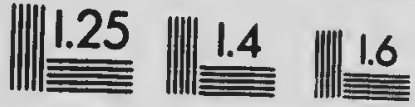

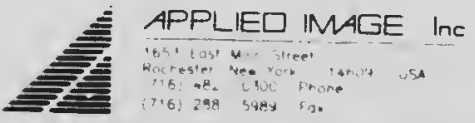




\title{
UNIVERSITY OF TORONTO STUDIES
}

\author{
BIOL.OGICAI. SIERIES
}

No. 14: EGG MATURATION, CHROMOSOMES, AND SPERMATOGENESIS IN CYCLOPS, BY Robert Chambers

THE UNIVERSITY LIBRARY: PUBLISHED BY

THE LIBRARIAN, 19:2 


\section{Univergite of Coronto studies COMMITTEE OF MANAGEMENT}

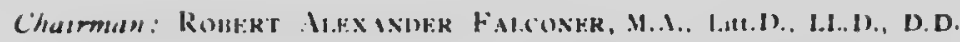
Prevident of the L'niversity

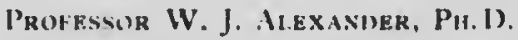

Professok W. H. lit.lis, M.A., M. B.

Professior A. Kirsillising, P'I1. D.

Professok J. J. M.icheszie, B.A.

Propessur R. RaMsay Wriciht, M..I., B.Sc., LL.D.

P'ROFESSOK GiEORLE M. WRONG, M.A.

General Eililor: H. H. I.ANGto:s, M.A.

Librarian of the Liniversity 


\title{
EGG MATURATION. CHROMOSOMES AND SPERMATOGENESIS IN CYCLOPS.
}

\section{Bir}

\author{
ROBERT CHAMRERS, IIA., PH.D.
}

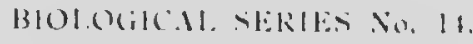

FRK.11.

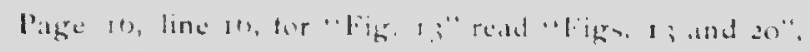

Page 28 , third line trom hast, for "chromsome" reat "chromatin".

Page in, sixth line from hist, low "Jen. Zeitsihr., 37 " read "Jen. Zevilschr., I. F., 3it". 


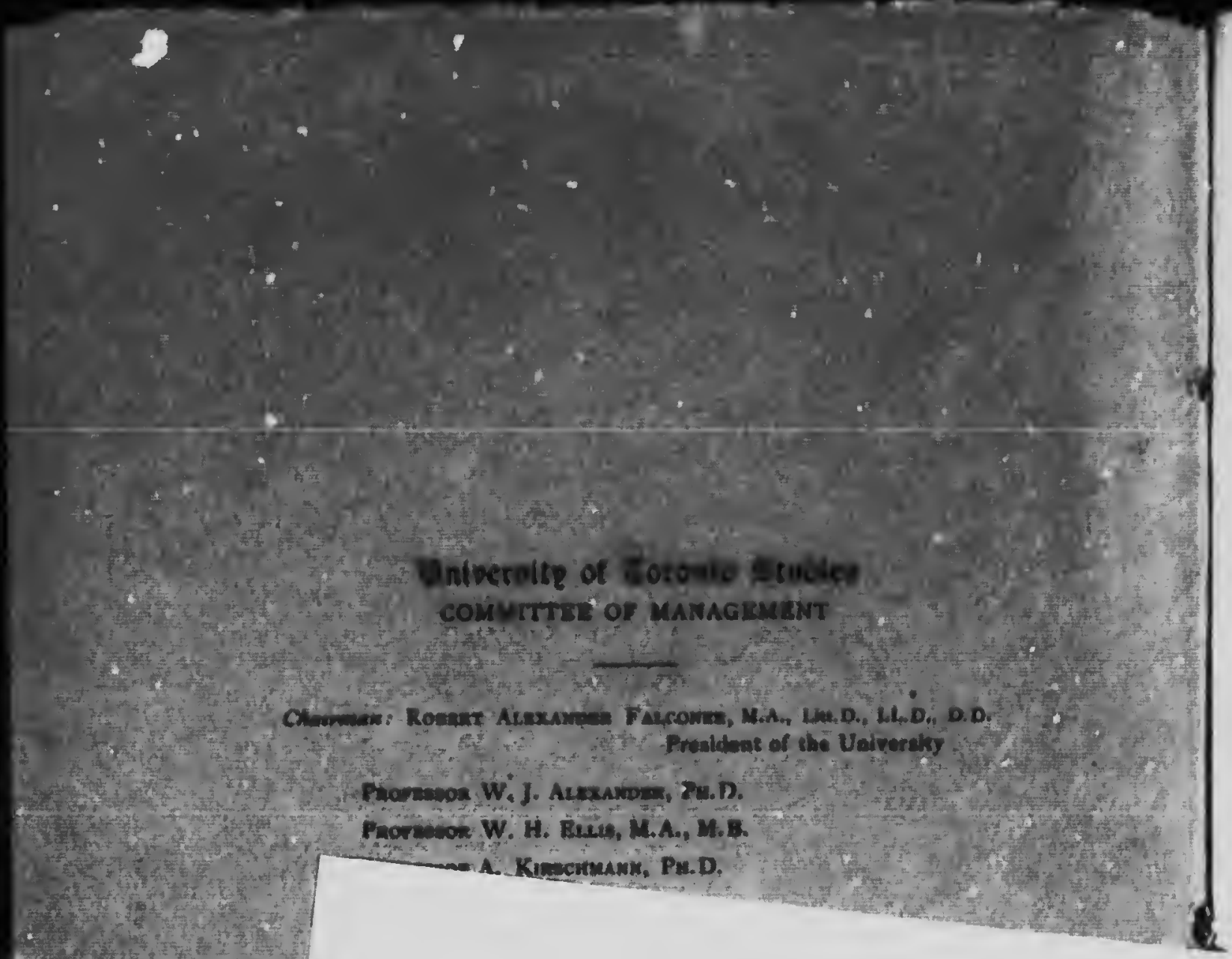




\section{EGG MATURATION, CHROMOSOMES AND SPERMATOGENESIS IN CYCLOPS.}

BY

ROBERT CHAMBERS, M.A., Pr.D. 


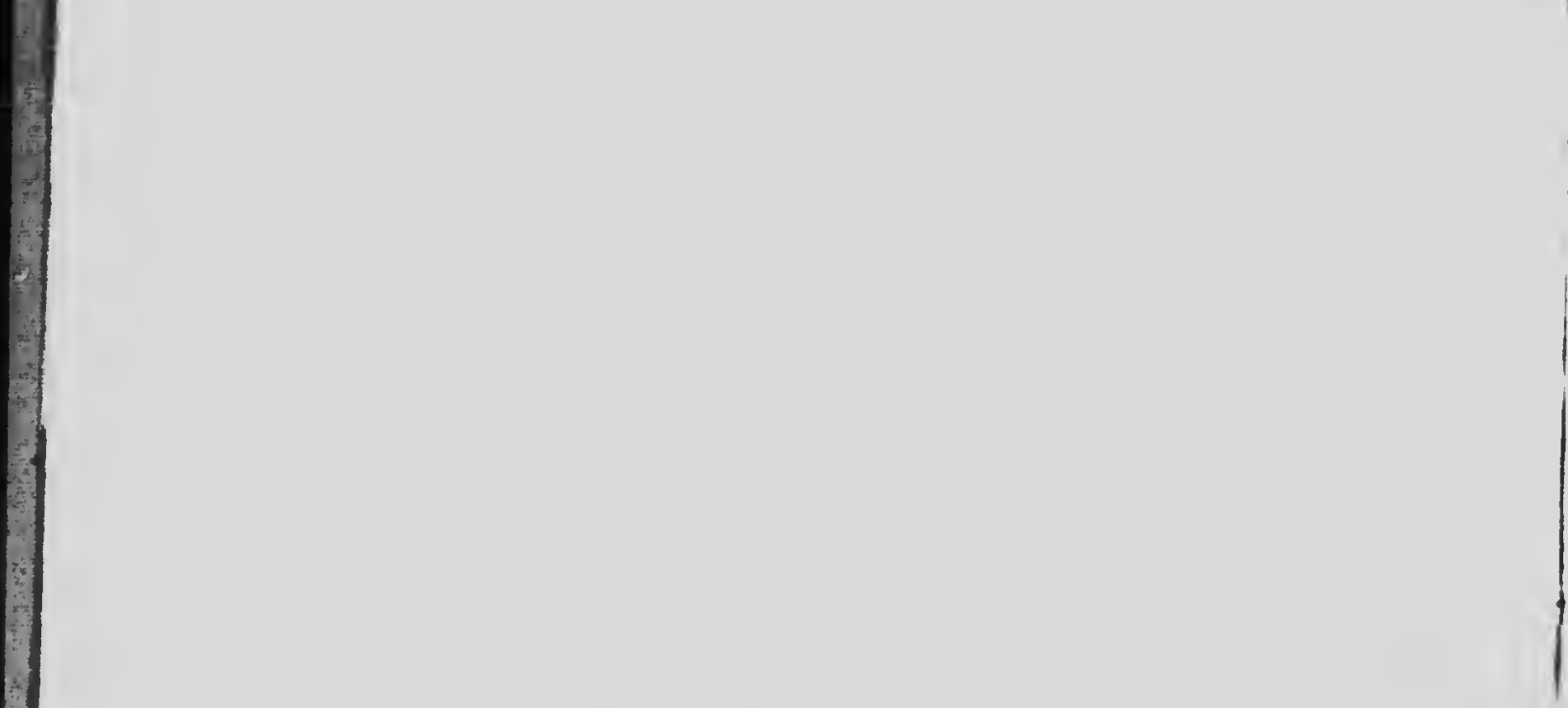




\section{TABLE OF CONTENTS.}

PAGE

I.-Introduction . . . . . . . . . . . . . . . . s

II.-Material and Method. . . . . . ...... 6

III.-The Cyclops "Tetrad" ..... . ...... ?

IV.-Maturation of the OVUM.............. 16

V.-Chromosome Number in Cyclops:

(a) Chromosomes in the Germ-tract . . . 17

(b) Chromosome Counts in Different Species 18

VI.-Chromosome Size-relations and ArrangeMENT in Cyclops parcus.............. 2i

VII.-Spermatogenesis in Cyclops americanus:

1. Literature........ . . . . . . . . . . 22

2. The Keimpolster................ 23

3. Multiplication Zone............... 24

4. Synizcsis and Synapsis Zore . . . . . . . . . 25

5. Early and Late Diakinesis. . . . . . . . . . . 26

6. Maturation.................. 26 26

7. Spermiogenesis... ................ 27

VIII.-Sugrapy......................... $\quad \mathbf{2 7}$

Literature Cited .................. 29

Explanation of PLAtes............... 34 


\section{EGG MATURATION, CHROMOSOMES AND SPERMATOGENESIS IN CYCLOPS.*}

\section{1.-InTRODUCTION.}

Most species of Cyclops show some degree of periodicity in their breeding habits. Cyclops viridis and its close relatives, $C$. parcus, brevispinosus, and americanus, with which this paper has most to do, may be found in sexual activity all the year round. They are, however, especially active during the spring months.

During copulation, the male, which is about one-third to one-half the size of the female, attaches a pair of spermatophores to the median ventral aperture of the seminal recepiacle which lies in the first abdominal segment of the female (cf. Wolf '05). The peculiar ejaculatory bodies in the spermatophores then swell and drive the spermatozoa in to the seminal receptacle.

Oogonial mitoses occur periodically so that there is always a number of cells in the same stage being gradually carried on ward through the ovary. When the oocytes pass in to the paired oviducts they grow very rapidly and, by distending the several branches of the oviducts, cause them to occupy the greater part of the interior of the cephalothorax. A gelatinous material fills the distal ends of the two oviducts, and as the eggs pass out this is pushed out ahead to form a large distensible sac in which the eggs come to lie (cf. Gruber 78). The eggs are fertilized as they roll in rapid succession out of the oviducts. Development is, therefore, comparatively uniform for all the eggs in buth egg sacs.

A female may lay six to seven batches of eggs, all of which may be fertilized by the spermatozoa derived from one male. These batches, consisting of thirty to fifty eggs, are

- Recummended for publication ill the University of Toronto Studizs by Irofessor R. Ramsay Wright, Profensor of Biology, University of Toronto.

Paper received llay, 1912 
generally deposited once every two to four days. The eggs are laid usually in the early hours of the morning (cf. Haecker 97). Ova showing maturation divisions I secured between 2 and 5 a.m., after having isolated the night before a number of gravid females. These are easily distinguishable because the yolk-laden eggs in their interior makes them appear black in transmitted light.

Spermatogonial mitoses exhibit a certain degree of periodicity which is by no means so marked as in the oogonial divisions.

Males are usually found in abundance together with the females. Their span of life, however, seems to be shorter than that of the females, and periods occur when few or no males are to be found.

\section{I1.-Material and Method.}

An easy method for collecting an abundance of material is the following: Scour the ditch or pond with a fine cheesecloth net; invert the net in a jas of water and shake so as to release the catch into the water; pour the water through a coarse sieve so as to get rid of leaves and larger undesired objects. Then pour the water into a funnel plugged with absorbent cotton. Wher the water has diained through, pick out the plug of cotton with a pair of forceps, turn it over and dip rapidly into the fixing-fluid. Most if not all the Cyclops will at once liberate themselves from the cotton and soon fall to the bottom of the fluid.

As fixing-fluids I have used sublimate alcoho! in various proportions both hot and cold, picro-acetic alcohol (McMurrich), picro formol (Bouin), Zenkerformol, Gilson's mercuronitric mixture, vom Rath's picro-aceto-osmic, Flemming's strong solution, Meves' modification of Flemming, and Carnoy's fluid (improved formula: glacial acetic, 1; absolute alcohol, 1; chloroform, I; the mixture saturated with corrosive sublimate).

For the early stages in the ovary and for spermatogenesis, 1 found nothing so good as Flemming's strong solution. For oviduct eggs (showing late diakinesis figures) warm sublimate 
alcohol ( 100 c.c. $70 \%$ alc., 5 grms. corros. subl., 0.2 grnis. $\mathrm{NaCl}$.; cf. Braun, ' 09 ), picroformol, and Carnoy's improved fluid gave very good figures. For ova in the egg sacs, show. ing maturation and early segmentation stages, I found Carnoy's improved fluid to be the best.

Material in warm $\left(40^{\circ} \mathrm{C}\right.$.) sublimate alcohol was left for about 20 to 30 minu:2s, then removed to $70 \%$ iodized alcohol. In Carnoy the objects were allowed to remain about 3 to 4 minutes when they sank. They were then at once washed in $70 \%$ iodized alcohol. Sections were made from 3 to $10 \mu$ in thickness. The nucleus of an ovum of $C$. parcus in the late diakinesis stage is, on the average, about $15 \mu$ in diameter.

As staining reagents, Heidenhain's iron haematoxylin was found to be the best for the oogonial stages and for spermatogenesis. Iron haematoxylin, Delafield's haematoxylin, and Babe's safrunin followed by light green were all used to advar.tage for staining late oocytes and the matur. ation and segnier.tation stages.

Investigation for this paper was begun in the University of Toron:o, carried on at Woods Hole and completed in the Biological Laboratory of Columbia University. I wish to acknowledge my indebtedness to Professor F. $\mathbf{R}$. Lillie for his kind courtesy in giving me a table at Woods Hole during the summer of I9II, and to Professor E. B. Wilson and Professor T. H. Morgan for the privilege of working in the Columbia Biological Laboratory and for their highly esteemed counsel.

\section{III.-The Cyclops "Tetrad".}

Four principal methods have been described to explain the formation of tetrads preparatory to the maturation divisions. These I have attempted to show in Text-figure I.

Text-fig. 1, Row 1.-The parasynaptic pachytene filament (a) splits to furm two parallel filaments (b) presumably' the same filaments that went into parasynapsis, except that during synapsis they may have interchanged material. Each filament then splits again longitudinally but in a plane 


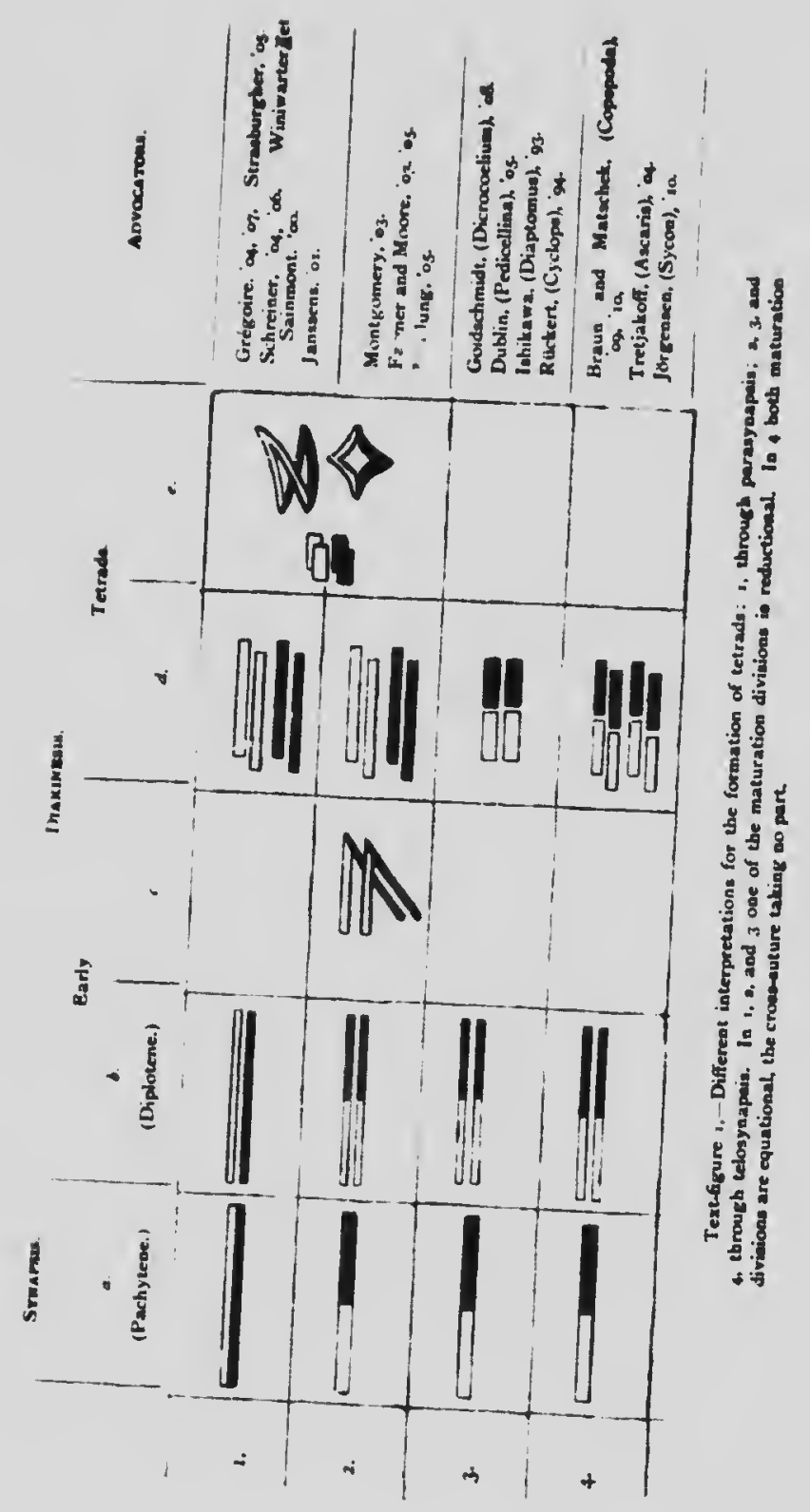


at right angles to that of the first split $(d)$. This tetrad may take on a variety of shapes according to the greater or less coruing to the one or the other of the splits and also acrods, forming rings, crosickening and shortening of the four

Row 2 . Thes, crosses, etc. (e).

lengthwise - The tclosynaptic pachytene flament (a) splits on thenselves $(c)$, along parallel filaments $(b)$. These fold telosynaptic filaments. bend to produce a tetrad filaments then break at the (I) and exhibiting the superficially resembling that of

Row 3.-The telosynaptic variety of shapes $(e)$.

as in (2). No folding, hor pachytene filament (a) splits break at the point of (d). One maturation snaptic union to form a simple tetrad spist, the other along thision is along the longitudinal

the cross-suture.

twice longitudinally. along the line of sym. The resulting filaments then break transverse break, or cross-in to produce a ditetrad. The in the maturation cross-suture (Querkerbe), takes no part Matschek, ('10), and Jörgen. It is interpreted by Haecker. pairs, of somatic chrorgensen ('Io) as the point of union, in They thus assume comosomes in the early germ-tract cells. germ-tract exist in the tie chromosomes throughout the

For Cyclops the haploid number

apsis spireme as consisting of a single ("94) described the synjoined end to end. breaks up in to rods half splitting longitudinally the spireme These longitudinally split rods (Tex chromosomes in number. a cross-suture which passes thiougt-fig. I, row 3) exhibit cates their bivalent nature. Though their middle and indidivides these tetrals along The first matuation division equatorial, the secrund pase their longitulinal split and is reductional.

Haccke

tetrads in Cauthocale game interpretation to the For Cyclops brevicus, a genus closely telated to Cyclops. different interpretation 


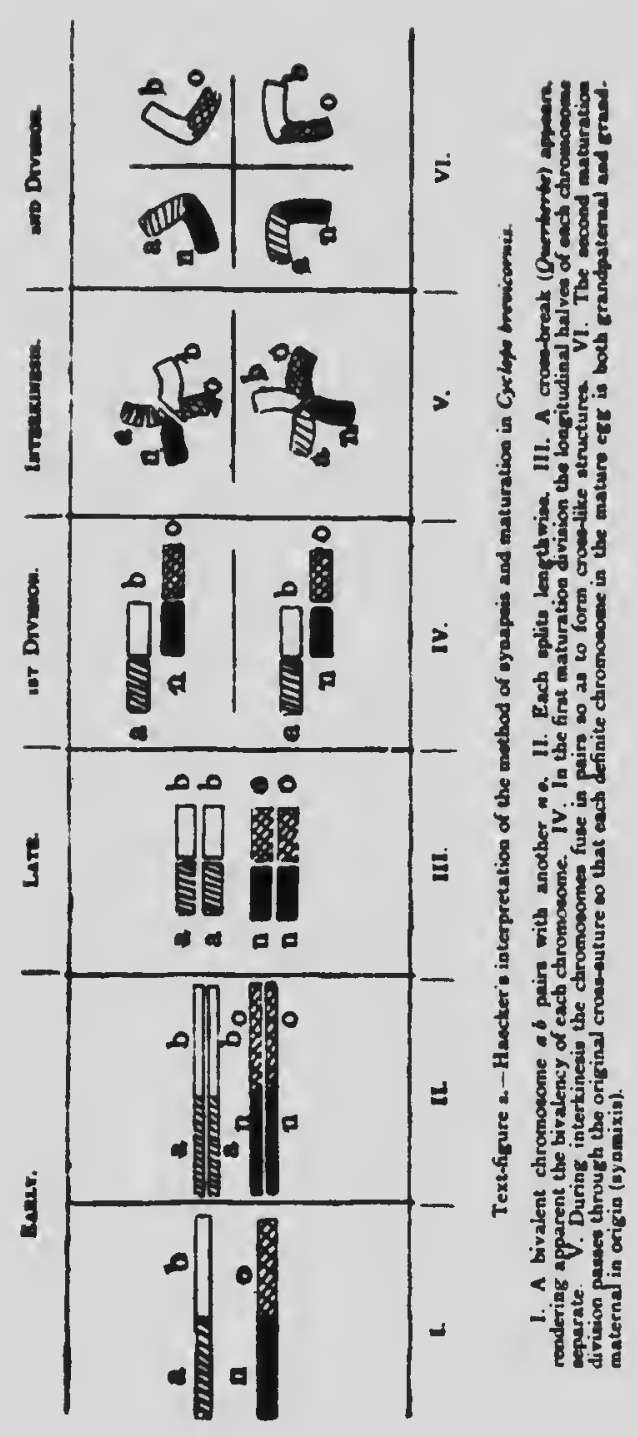


possessez twenty-four somatic chromosomes. In the germtract the chromosomes are twelve in number, each consisting of two chromosomes joined end to end. In the oocyte these (Text-fig. 2, I) chromosomes arrange themselves into pairs (II) and also breaks across a pair then splits lengthwise telosynaptic union (III). Each pair, the of the original into a titetrad or two tetrads lying parallerefor, is formed During the metaphase of the first marallel to one another. tetrads are so arranged, six in each of two parallel planes, opposite, another parallel to, and directly sumed that the setrad in the other plane (III). He asand the other six tetrads in the one plane are of paternal, spindle the longitudinal, origin. In the first maturation to separate poles During interkinesis, the division being homœotypic. pairs become contiguous two dyads of the formerly opposite form double $V$ figures and fuse at their middle points to second maturation spint $(V)$. The plane of division in the through the cross-n spindle, as in other copepods, passes of the fusion of original tetrads, but because somes which go to the pols into double $\mathrm{V}$ figures, the chronobut consist of poles of the spindle are still bivalent, synmixis of both grandpaternal and grandmaternal (VI). A matin elements is thus produced within the pronucleus.

This assumption of synmixis during interkinesis, based merely on the fact that the tetrads of $C$. brevicornis are peculiarly X-shaped, is elaborated by Haecker in order to account for the presence in the male or femaie pronucleus of both grandpaternal and grandmatemal chromatin elements. The assumption is made necessary because of Haecker's claim that gononery obtains in the germ-tract nucleus,

Unfortunately for both Rückert and Haecker, recent investigations have placed the Cyclops tetrad in a very different

Braun ('o9) in a study of some sixteen Cyclops species described paired chromosome rods which are longitudinally split and cross-sutured (Text-fig. I, row 4). He also showed 
that the peculiarly $\mathbf{X}$-shaped tetrads of $C$. brevicornis are not produced during interkinesis but exist already in the oviduct egg and are due to the divergence at their ends of the longitudinal halves of the tetrads. Compare this with my own observation, Pl. I, Fig. 4. The first maturation division separates the two parallel sets of tetrads; the second separates the diverging longitudinal halves of the tetrads.

Matschek ('10) made an extensive study of tetrads in species belonging to six families of the Copepoda. He agrees with Haecker and Rückert in regard to the origin of the tetrads from an incompletely segmented longitudinal spireme. He confirmed Braun's discovery, howeve1, that Rückert's tetıads are really ditetrads or octads (Text-fig. 1, row 4). The oogonial chromosomes being twelve in number, there are six ditetrads in the ovicluct egg. The primary longitudinal split is much bioader than the secondary, so that the ditetrad gives the appearance of two tetrads lying parallel to each other. The two maturation divisions divide the ditetrad along the two longitudinal splits. The cross-suture being interpreted as the place of conjunction of two chromosomes and taking no part in the maturation divisions, Braun and Matschek consider both maturation divisions equational.

Lerat ('05) discountenanced the existence of the crosssuture in Cyclops. He worked on a variety of Cyclops strenuus found in ditches, the same species studied by Rückert. According to Lerat's description leptotene filaments in the young oocyte conjugate in pairs by parasynapsis to form pachytene filaments. These subsequently split along the line of conjugation (cf. the split spireme of Haecker, Rückert and Matschek). As the filaments shorten and thicken, they form paired chromosomes. These show no signs whatever of a cross-suture. Lerat did not go beyond the metaphase of the first maturation division.

It is interesting to note here that Braun mentions the case of a winter form of $C$. sirenuus, living in ponds which dry up in the summer. In this form the chromosomes are long and U-shaped and the cross-suture is barely noticeable. Other individuals of the same species, living in lakes or in small ditches throughout the summer, possess chromosomes 
with a very distinct cross-suture. Lerat may have studied only the winter form. The apparent contradiction in the statements of Lerat and Braun concerning the cross-suture may also be due to the fact that the two used different killing and staining fluids. Lerat used Gilson's mixture and Heidenliain's iron haematoxylin. Braun used sublimate alcohol and Delafield's haematıxylin.

Miss Krimnel ('10) is the latest to describe tetrads in Copepora. She made a study of the generative cells during the late mbryonic develonment of Diaplomus coeruleus. In her preparations she finds cross-sutured chromosomes both in oogonial and in somatic cells. The chromosome number in the germ-tract she claims to be thirty-two. In the somatic cells, however, she finds the number to vary anywhere from sixteen to thirty-two. Her paper is a preliminary report. We may defer criticism therefore, until her complete paper is published.

Tetrads whose cross-suture take: no part in either of the two maturation divisions have been described in few forms outside the Copepoda.

Tretjakoff ('O4a) in the egg maturation of Ascaris megalocephala bivalens described two chromosome groups tach consisting of two parallel chromosones, each of which is longitudinally split. A transverse suture often appears in the middle of these split chromosomes which later on disappears without taking part in the maturation divisions.

In a later paper ('o4b) Tretjakoff described the shape of the prophasic spermatocy te chromosomes of Ascaris that may well account also for the transierse suture he saw in the prophasic egg chromosomes. The chromosomes first appear as ribbon-like bodies with thickened ends. Later their middle region becomes so narrow as to consist of a mere thread connecting the two ends. Tretjakoff suggested that the middle region of the chromosomes consists of trophochromatin, and the two ends of idiochromatin. During the maturation stages the trophochromatin disappears, thus giving the chromosomes the appearance of being broken in the middle.

Boveri ('o4) and Montgomery ('o4), however, and more recently Griggs ('06), mention no such suture in the Ascaris 
forms studied by them. This and the general appearance of Tretjakoff's figures make one rather sceptical of its normal occurrence in Ascaris.

Marcus ('06) in Ascaris canis described a cross-suture giving the tetrads the appearance of ditetrads. Edwards ('II), however, in a closely related species, Ascaris felis, found nothing of the sort.

A very recent paper which describes a condition similar to that of the Cyclops tetrad as explained by Haecker is one by Blanckertz ('11). Blanckertz describes eight "chromosomes" in the first maturation prophase of Ascaris megalo. cephala univalens. The eight fuse end to end, in pairs, to form the four elements of the Ascaris tetrad. Each element of the tetrad is thus bivalent in the sense of Haecker's bivalent Copepol chromosumes.

In Sponges, Jörgensen ('o9) describes in a Sycon eight tetrads which appear in the first spermatocyte equatorial plate. During metaphase I the tetrads split into dyads which in the anaphase appear again as tetrads. In metaphase 11 these divide again into dyads. The spermatid chromosomes thus arpear to be bivalent.

Tetrads have been described by Buchner ('og) as being found also in the oogonial cells of Gryllus.

The artificial production of such structures in somatic cells and in the egg (Haecker, 'oo; Schiller, '08; Della Valle, o9) through the action of the strychnine and other poisons should render us cautious in accepting statements as to their normal occurrence in cells, at least where chromosomes are known to be diploid in number.

My own observations have been limited to Cyclops americanus, $C$. parcus, and $C$. brevispinosus.

Double chromatin filaments in the reduced chromosome number come out of the synizesis stage and persist as such throughout the growth period of the ovum. The two elements of the clouble filament, which are at first close together, separate more and more as they contract to form short paired rods. During the late prophase of the first maturation division these paired rods are scattered throughout the nucleus (PI. 1, Fig. 4.) 
When the nuclea. wall breaks down, the paired rods are drawn into the biserial arrangement (Figs. 5-10).

From a careful study of a large number of sections of this stage in $C$. americanus, parcus and brevispinosus, I am convinced that the so-called Querkerbe, or cross-suture, is not an actual brcak but rather a clear area of the chromosome due to the faint staining power of that region. The chroniosome rod is somewhat larger at its two ends than along its middle. If we assume that this narrower, more faintly staining region is easily hroken through when effected by killing reagents, we may account for the presence of a cross-suture in so many recorded instances.

Fig. 9 gives the side view of several chromosome pairs from different oviduct eggs in the same individual. All werc found 'on the same slide so as to insure as far as possible uniformity in fixation and staining action.

That the cross-suture, or rather the clear area, frequently does not lie in the middle of the chromosome rod has been commented upon by Rückert himself ('94, p. 308). An instance of this is to be seen in Fig. 9a. It is noteworthy that the clear area is alw in the same region for the two rods of the same pair. - ib shows onc rod completely broken into two portions, pi sably an artifact, for its mate is in. tact. Fig. $9 \mathrm{c}$ shows the clear area in the middle gd exhibits a condition very frequent in my preparatu. when the rods show no sign whatever of a clear area.

During all stages except that of he biserial arrangement the chromosomes are U-shaped. Here only do the two arms of the chromosome stand out to form a more or less rigid rod. May not the sameforce that holds them in this way cause a massing of the chromatin substance toward the two ends? This would leave an achromatic sub. stance in evidence at the middle.

The suggestion that a chromosome cunsists of two sub. stances, an achromatic framework or substratum and a chromatic substance, is in accordance with the view of Bonnevie ('II) for Allium and Amphiuma, that a chromosome consists of an achromatic core around which is coiled a chromatic spiral thread. 


\section{!V.-Maturation of The OVUM.}

Just before the eggs pass out of the oviduce a serond nuclear membrane differcitiates, enclosing a much smaller area than the former nuclear membrane of the germinal ves.cle (Pl. I, Fig. 10).

Uron fertilizetion, an the engs pasa out of the oviduct. this secomlary nucleus approaches the periphery of the egg. No typical metaplase figure is cver fornecl, the chromosome pairs in the hiserial arrangenent passing directly into anaphase I (Figs. 11, 12, 13).

As Matseluck has alrearly observeel, the first polar bedy is tormed within two (1) three minutes after the egg is laid. Very little, if ally, cytoplasm is given of with the polar borly. As the nuclens mose's to the periphery of the yolk-laden

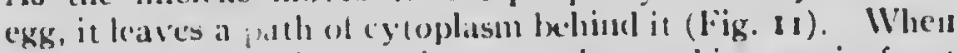
it reaches the periphery it protrudes, pushing out in front of it a membrane (lif 13). During the late anaphase the chromosones an-ume their original U-shape, and froun now on 110 sign whatcece of the clear area in their midelle ean le secen. The nuclear membrane remains infact untit a constriction at its nidclle occurs which finally cuts of the polar bouly.

Matseleck's ligure's ane remarkable because of the peculiar distinctness with which the "ross-silture" is depieted during maturation divisoms. Iy examining my obiects with the

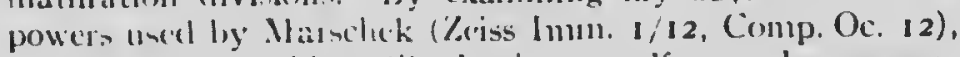
I found that 1 could realily aleceive myself ats to the presence of a cross-suture by not laking into account the U-shape of the ehromesome, for the midlle portion of the chromosome is inft out of focus at the time that the two ends are in view.

That side of the merclear nembrane from which the polar boly is constricted off slows a break for some time (l'l. 2 , Fig. 14). It is soon repaired. however, to form a closed nucleus in which the split chromosomes arrange theniselves for the serond alivision by turning $\left(0^{\circ}\right.$ on their axes. The split halves now are drawn astuder by spinclle fibres which are distinctly visible (in contrast to those of the first inaturation division) (Figs. 17, 18, 19). The metap'lase figures 
AC similar to those of the oogonial chromosomes, the spindle hbres being attached medially or subterminally.

Fig. 20 shows the second polat borly alout to be constricted of The chromesomes are somewhat massed together in the telophase. The nuclear ineinlorane is still intart.

In Fig. 21, the prolar forly has le'en given off and the female pronucleus has recerlecl into the egg. surrounded by a very indistinet membrane. The chronosomes are losing their definiteness of outline and will secon form the reticulum of the female pronucleus.

Fig. 22 is is polar view in C. parcus of the male and female pronuclei lying in the first sermentation spindle. The three chromosones of one of the ponuclei, presumably the fentale pronucleus, are already definitely fornici and are beginning to show signs of splitting.

llaceker and his p'pils, also Rückert, and Ishikawa, have already described the remarkable antonomy of the mals and female pronuclei luring the earlier segmentation proresses. The autonomy goe's so far that one may often observe two almost complete spindles side by side each with its proper chromosomes.

\section{V.-Chromosome Numili in Cyclops.}

$$
\text { (a)-CHROMOSOMES IN THL CERM-TRACT. }
$$

There is $r$, doubt that the chromosomes in the germtract cells arc unreduced in 11 umber. Krimmel is) has shown this to occur in Diaptomus. In Cyclops americanus I have been able to make out ten U-shaped chroinosones in several tissue cells. That the chromosomes occur in the same numbur in the oogoria and spermatogonia of the same forill may be seen from Fig. I aud Figs. 26, 28, 29.

The conclusions of Krimnel and myself are contrary. to the statenients of voin Rath ('95) who observed thirtytwo elements in the mitoses of the alimentary canal cells of Anomulocera patersonii, a marine Copepod, and sixteen 
elements in the mitoses of the oogonia; and Matschek ('ro) who figures an oogonial anaphase in Cyclops fuscus showing seven chromosomes, whereas in the biserial arrangement seven pairs are to be found.

Figs. 2 and 3 show the six orgonial chronosomes in $C$. parcus. The chromosomes are usually U-shaped and apparently very plastic in nature. During the cogonial metaphase they split longitudinally and in the anaphase the slender halves shorten to form thick, semi-curved cliromosomes of about half the length of the mother chromosomes. In none of my preparations is there any figure approaching that of a tetrad such as Krimmel depicts in the Diaptomus germ-tract cells.

\section{(b)-CHROMOSOME COUNTS IN IMFFERENT SPECIES.}

Braun ('og) and Matschek ('10) have ascertained the chromosome counts for sixte" - if the European species of Cyclo, ;. Braun made a study of the relation between the chromosome number and tle external specific characters of the species. Taling the condition of the fifth rudimentary foot and the number of antennal segments as criteria, he found in general that those which show least signs of rudimentation possess the greatest number of chromosomes. He made the following conclusions: (I) that the highest developed forms (e.g. many marine Cyclopidae) possess the greatest nur.'ber, and those which are most highly specialized possess the smallest number, of chromisomes; and (2) that closely related species possess equal or nearly zqual chromosome counts and, therefore, that the chromosome number may be used in the determination of species relationship.

As far as I have been able to make nut. the chromesone counts for American species hit well into Braun's phylogenetic scheme. On the other hand, his statement that closely related species possess equal or nearly equal chromosome counts is quite untenable, at least for our American forns. The following table gives the specie's with their iliploid chromosome counts as I have found them: 


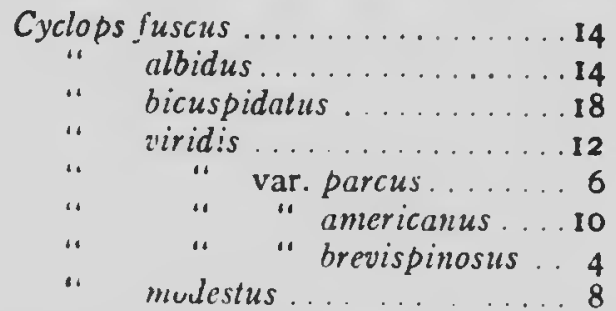

C. fusc:ts, albidus, bicuspidatus, and viridis (cf. Chambers, '12) are merphologically illentical with their European representatives. Their ciromosnrie numbers are also identical with those founc by Braun and Matschek. The other species nentioned in the table appear to have no European representatives. In the latest revision of the North American species of Cyclops, Marsh ('10) classifies C. americanus, parcus, and brevispinosus as American varieties of the Eurupean C. viridis Jurine. C.viridis (typ. sp.) has been described only by me as bring found in American waters.

In their external features $C$. americanus, parcus, and brevispinosus are barely distinguishable, the only main difference being the number of spines on the terminal segments of the swimming feet. (Text-fig. 3). It has been suggested (Byrnes, '10) that parcus and americanius are two phases in the lifehistory of the same form. I have discusse $I$ this matter elsewhere ('12). Americanis and parcus breed true for ger.erations. Slight variations in the number of spines of the swimming feet among individuals of the same culture occasionally occur. but the chromosome number always remains constant.

Cyclops brevispinosus differs fror: americanus and parcus in frequently becoming sexually mature before the swimming feet attain the number of spines characteristic for that variety. We may therefore have a parcus-like form (Text-fig. 3, c) or an americanus-like form (Text-fig. $3, d$ ) except for the presence of a spine on the outer side of the te:mital segment of the endopodite of the fourth swimming foot and the presence in the cells of four chromosomes.

- The caudal styles of $C$. brevispinosus are slightly thicker and shorter than those of $C$. p.rous and $C$. americanus. All three are abundant in ditches and prols, although not associated in the same pool. The three appear equally infested with a unicellular green 2 lga which often covers them completely. 


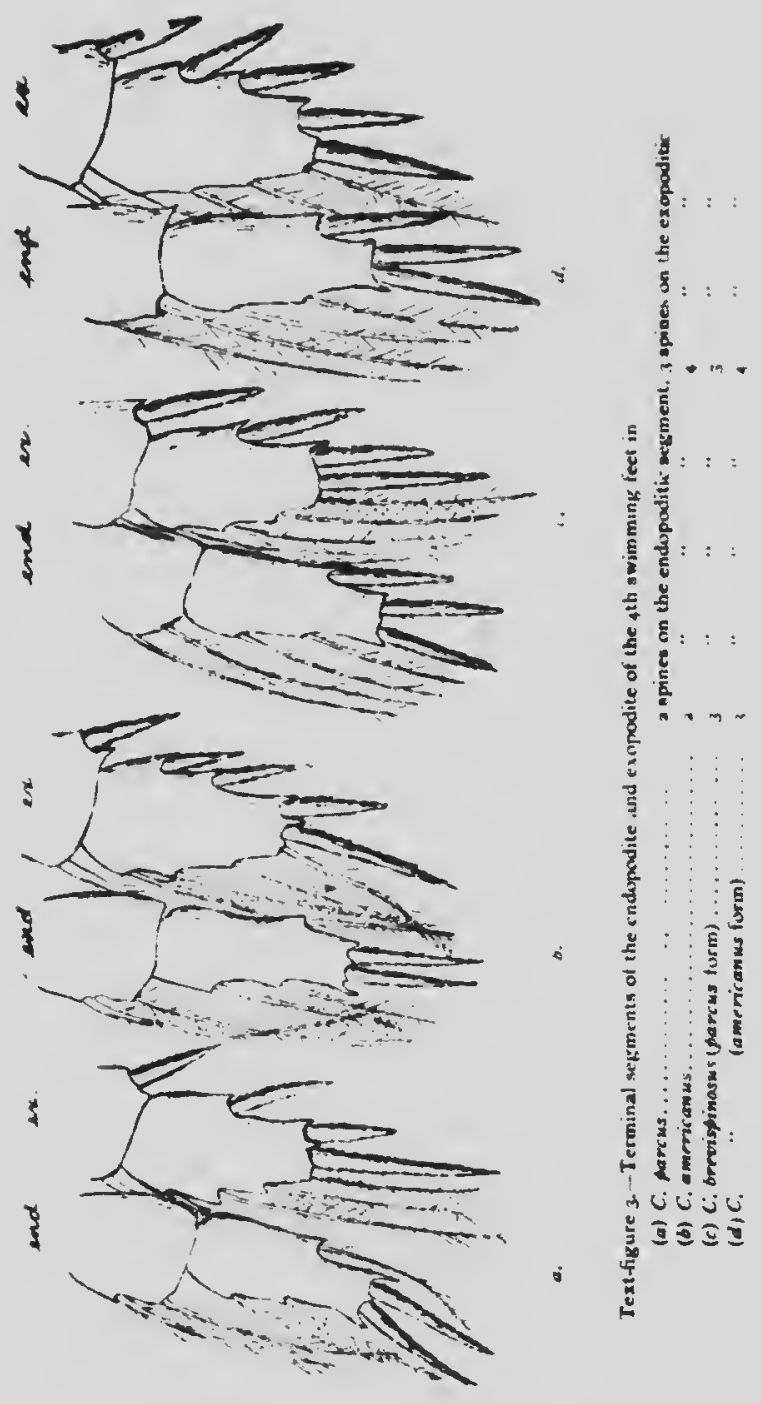


C. viridis (typ. sp.), averaging $2.2 \mathrm{~mm}$. in length, is the largest form in the viridis group (excluding occasional giant forms of all the varisties). It has twelve chromosomes. C. brevispinosus with four chromosomes comes next, averaging $1.6 \mathrm{~mm}$. in length. C. americanus with ten chromosomes, and $C$. parcus with six chromosomes, come last and are barely distinguishable from each other in size.

The size of the chromosomes varies greatly in the three varieties, $C$. brevispinosus possessing by far the largest, and C. americanus the smallest, chromosomes. The proportions for the different forms are such that we could readily assume a relationship between the average sizes and the amount of their chromatin content.

An explanation of the discrepancy of chromosome number in closely related forms is offered by Wilson ('o9) in the following words:-

"It seems to me a natural view that the nucleus consists of many different materials or substances that segregate in a particular pattern; that different chromosomes need nct, however, represent a complete separation of different substances but are in many cases perhaps in all, compound bodies; and that the particular form of segregation may readily change rom species to species. Marked or even extreme changes ...ight have taken place in the number and size relations of the cirromosomes that would involve little or no change in the essential quality of the nuclear substance, and the apparent anomaly presented by differences in the chromosome groups of nearly related forms would disappear."

\section{VI.-Chromosome Size-RElations and ARrangement in Cyclops parcus.}

In $C$. parcus the six somatic chromosomes occur in three sizes, there being a $F^{\text {nir }}$ for each size.

Pl. I, Fig. 2 shows the oogonial chromosomes on the point of being arranged in the equatorial plate. In spite of the fact that they are somewhat bent, one may readily pick out the pairs, two long, two medium-sized, and two short chromosomes. We may see here as Wilson ('06) has already pointed 
out for Anasa and other Hemiptera that the cliromosomes of a pair do not necessarily lie together in the nucleus, an as. sumption held by many bntanists.

The constancy with which the chromosomes retain their relative size during the different stages of maturation may be seen from a comparison of Figs. 2, 6, 15, and 22.

During the biserial arrangement the chromosomes of a pair lie parallel to each other. An exception is the case of one of the pairs in an individual taken from a cultuie of $C$. parcus. This individual possessed an abnormal number of spines on the terminal segment of the external rami of the swimming feet, the number for the four feet being, istic number for parcus. eggs were found parcus. The chromosones of the oviduct smallest pair she in the biserial arrangement, and the some fifty or eighty, a deviation constant for all the eggs, rods instead of lying parallel the tho chromosome for the other pairs in this to each $\mathrm{er}$, as was the case angles to each other (Fig. 7). It is lay almost at right abiormal arrangement (Fig. 7). It is remarkable that this vidual.

\section{VII.-Spermatogenesis in Cyclops americanus. \\ I. -LITERATURE.}

Ishikawa ('93) described the spermatogenesis of a Diaptomus sp. He gives eight to be the so.natic chromosome number. After the loosening of the synaptic clump he makes out, rather doubtfully, eight filaments. These shorten to form the definite chromosomes of the spermatocyte of the first order. He describes no t The first maturation division is equatorial and the second is reductional, four of the eight clironzosumes going to one pole and four to the other. His evidence, however, is very
doubtful.

Haecker has published no account of spermatogenesis in Copepoda except a brief mention in his paper of 1902 There he figures a longitudinal section of a young Heterocope testis 
1.

\section{Chambers: Chromosomes in Cyclops}

tu illustrate his contention that the paternal and maternal elements of the nucleus in the grown cell keep more or less independent of each other. He figures numerous nuclei to show their dual nature as evidenced by the ir bilobed appearance and the possession of double nuclei. In two in. stances two independent spiremes are shown in one prophase nucleus. In the spermatid his figures show double nucleoli very prominently. In two of the spermatocyte nuclei he figures distinct tetrads.

Lerat ('05) gave an account of the spermatogenesis in Cyclops strenuus. Although he was unable to count the spermatogonial chromosomes, he assumed them to be unreduced in number. He claims that reduction takes place through parasynapsis as the chromatin filaments come out of the contraction stage. His studies went no farther than the anaphase of the first maturation division, but in that stage he rigures the daughter chromosomes split lengthwise preparatory to the second maturation division. He found no sign whatever of tetrarls.

In Cyclops americanus the testis is single and median, lying immediately under the dorsal wall of the thorax. From its anterior end two vasa deferentia rise, and after winding several times, one on each side of the alimentary canal, pass back to open, one on each side of the first abdominal segment.

\section{2.-THE KEIMPOLSTER.}

In old individuals a cup-shaped depression containing a disorganized mass is to be observed at the blind end of the testis (Fig. 24). This depression indicates the location of the Feimpolster, or primitive germ-cell group, from which the iestis is derived.

In immature indiviuuals the Keimpolster is a rapidly proliferating mass of cells (Fig. 23).

In young sexually mature individuals it appears as a syncitium containing a number of cleply chromatic nuclei rather irregularly disposed but chiefly arranged along the periphery. The nuclei are small, barely two-thirds the size of the largest spermatogonial nuclei. Heavy strands of chromatic material cause them to acquire a dense stain. 
The absence of mitotic figures in the Keimpolster of all sexually mature individuals, and the fact that the Keimpolster is separated from the testis proper by a sharply defined boundary, renders likely the supposition that, after producing a number of spesmatogonia, it becomes inert and soon disorganizes, the growth of the testis henceforth being due entirely to spermatogonial mitoses.

This Keimpolster corresponds to that described by Haecker in Cantnocomptus and is, according to hin ('95a), to Amma ('10), and to Krimmel ('10), the direct descendant of the germ-cells differentiated as early as in the first cieavage of the egg.

Lerat ('05) was unable to find a typical Keimpolster in c. strenuus, He describes an apical cell from which he assumed the spermatogonial cells were derived. It is much more probable that this "apical eell" is merely one of the spermatogonial cells and that he failcel to find the true Keimpolster as it may have been already disorganized in the individuals studied by him.

\section{3.-MULTIPLICATION ZONE.}

The region following the Keimpolster consists of a large number of proliferating spermatogonia forming a mass of closely appressed cells. Lerat figures this region as a syncitium. My preparations, however, give clear evidence of definite cell boundaries (Fig. 24). The resting nucleus (Fig. 25) possesses an irregularly blotched chromatic reticulum. Division figures are periodically frequent (Fig. 27). Definite spindle fibres are plainly visible. The chromosomes in the equatorial plate are diploid in number and are more or less U-shaped (Figs. 28, 29).

The size of the cells varies greatly, owing partly to difference in tine of growth and partly to the nuniber of spermatogonial divisions that the cells have passed through, the nuclei and cells near the blind end of the testis (Figs. 25, 28) being cousiderably larger than those about to pass into the synizesis stage (F: 5 s. 29, 30). 


\section{4.- - SYNIZESIS AND SYNAPSIS ZONE.}

The term synapsis is generally used indifferently by European writers for the massing of the chromatin filanients in a nucleus and their conjugation. The term synizesis, first proposed by McClung ('05), is much more applicable to the massing of the chromatin, while the term synapsis ought to be restricted to the conjugation of the filaments.

In Cyclops there is a decided synizesis stage. The chromosomes o: the last spermatogonial division do not pass directly into the synizetic filaments, there being an appreciable zone of resting nuclei next to the synizesis region. Figs. 30 to 33 represent a number of contiguous nuclei in which one may see the gradation betweer the irregular network of the resting nucleus and the entangled mass of fine threads in the synizesis nucleus.

A distinct sub-spherical nucleolus is noticeable at thir stage. It is always situated at one side of the synizetic mass. No bouquet-like orientation of loops can be distinguished but the threads are clearly leptotene filaments. The nucleolus never attains the great size and irregular shape seen in Lerat's figures. It is somewhat rounded in outline, rather small, and never shows the intimate connection with the chromatin filaments as figured by Lerat. Lerat's figures give one the impression of incomplete extraction of the haematoxylin stain.

The nuclei of the cells undergoing synizesis are never larger than the small last spermatogonial nuclei. Gates' interpretation ('og) that synizesis figures may be due to the growth of the nucleus unaccompanied by growth of the chromatin content, cannot apply, therefore, to the case of Cyclops.

No positive result was reached as to the likelihood of para- or telo-synapsis taking place during this stage. Thers: seems to be no doubt, however, that synizetic nuclei containing leptotene filaments exist together with synizetic nuclei contusining pachytene filaments. The two types of filamerts are easily distinguishable, there being no intergradations such as Matschek clainis to be the case in the 
oogenesis of Cyclops. Nuclei with pachytene filaments (Fig. 34) are most numerous in the region farthest from the spermatogonial zone.

\section{5.-EARLY AND LATE DIAKINESIS.}

As the synizetic coil begins to loosen, the pachytene flaments give the appearance of being lumpy along their lengtlıs (Fig. 34). Numerous short splits longitudinally arranged on the filaments soon appear (Fig. 35). The coil finally resolves itself in to five long filaments each consisting of two filaments tightly twisted about each other (Fig. 36). The spirals untwist as these filaments thicken (Figs. 37, 38, 39) until the five paired definite chromosomes of the spermatocyte of the first order are formed (Fig. 40).

There is a slight growth of the cells during the synizesis and early cliakinesis stages. In the oocyte there appears to be some connection between cell growth, which is enormous, and the simultaneous increase in size of the nucleolus which is very great. In the spermatocyte. on the other hand, where growth is ccinparatively slight, no appreciable increase in size of the nucleolus is to be observed.

The two elements of the bivalent chromosomes are distinctly elongate dumb-bell-shaped. In one individual I found several spermatesytes of the first order which contained four bivalent chromozomes and two single elements lying at some distance from one another (Fig. 41). Undoubtedly the two single elements are halves of the fifth bivalent chromosome which have accidentally broken apart.

\section{6.-maturation.}

The spindle in Division I is an ordinary one with conical poles and numerous fibres (Fig. 42) and with no resemblance to that in the maturation of the ovum. Insertion of the fibres is either subterminal or median. In metaphase the two halves of the bivalent chromosome usually break away first at one end (Figs. 42, 43). The split in the chromosomes for Division II appears during A naphase I (Fig. 44). In telophase (Fig. 45) the cliromosor es become somewhat massed 


\section{Chambers: Chromosomes in Crclops}

together but their distinctness is never lost during interkinesis. During this time the split in each chromosome becomes very prominent (Fig. 46), each half appearing distinctly dumb-bell-shaped. In Division II the chromosome halves are drawn away from each other much as in Division (Figs. 47 and 48). The spermatocytes of the second order (Fig. 49) contain five slender dumb-bell-shaped chromosomes.

\section{7.-SPERMIOGENESIS.}

The more or less rigid dumb-bell-shaped chromosomes become U-shaped (Fig. 50). They then lose their distinctness of outline through the appearance of irregular projections over their surface (Fig. 51). These projections grow and develop in such a way that a hollow sphere of a reticular chromatin mass is formed (Fig. 52), similar to that described by Montgomery ('12) in the spermiogenesis of the Peripatus. The sphere is then drawin out into the form of a spindle (Figs. 53, 34). As the spindle lengthens, it becomes compressed from side to side. At the same time it increases somewhat in size, and the small anount of cytoplasm originally about the sphere appears to be sloughed off.

The spermatozoon in the vas deferens (Fig. 55) is a slenter, faintly staining, finely reticula: mass with a slight spiral curve and !ong tapering ends. In cross section it appears narrow ovate (Fig. 55a). In the seminal receptacle of the female the spermatozoa are often curleci in the form of a corkscrew.

$$
\begin{aligned}
& \text { VIII.-SUmmary. } \\
& \text { EgG maturation in Cyclops americanus, parcus and } \\
& \text { brevispinosus. }
\end{aligned}
$$

1. The oogonial and spermatogonial chromosomes are diploid in number.

2. The tendency for the chromosomes, both of the oocyte and if the spermatocyte, to assume a characteristic $U$. shape seems to be subordinated during the prophase of the first maturation division to a force which causes them to assume a more or less rigid rod-shape, somewhat swollen 
at the ends. In the oocyte this massing of chromatin at the ends leaves a clear area in the middle of the chromosomes. Such a clear area does not appear in the spermatocyte chromosomes.

3. Both egg-maturation spindles are entirely within a nuclear membrane. The spindle fibres, attached subterminally or miedially to the chromosomes, appear most distinctly in the second maturation spindle. The spindle poles are very broad so that the fibres appear to run almost parallel to one another.

4. The four American "varieties" of Cyclops viridis exhibit a constant difference in chromosome number. $C$. viridis (typ. sp.) has twelve, var. americanus has ten, var.parcus has six, and var. brevispinosus has four chronısomes.

5. The six chromosomes of $C$. parcus are in three sizes, there being a pair for each size. The chromosomes of a pair do not necessarily lie together in the spermatogonial or oogonial nucleus.

\section{Spermatogenests in Cyclops americanus.}

o. In the mature Cyclops a Keimpolster distinct from the adult testis may exist.

7. Nuclei in synizesis are smaller, if anything, than the last spermatognnial nuclei. In the testi synizesis is accompanied with only a very slight growth.

8. The nucleus in synizesis resolves itself into five pachytene filaments, from each of which develop two fila. ments, spirally coiled about one another. The five double filaments uncoil and become the five paired chromosomes of the spermatocyte nucleus.

9. The single elements of the double spermatocyte chromoscmes are elongate, dumb-beil-shaped, similar to those of the oocyte.

10. The spermatid chromosomes resolve into a hollow sphere of a reticular chromosome mass. The ripe spermatozoon consists of the spermatid nucleus drawn out into a slightly spiral spindle-shaped body, with fine tapering ends. 
Amma, $K$.

\section{Literature Citei,}

1911. Uber die Differenzierung der Keimbahnzellen bei den Copepoden. Arch. f. Zellf., 6.

Blanckertz, R.

1911. Die Ausbildung der Tetraden in Ei vom Ascaris megalocephala univalens. Arch. f. Zellf., 6.

Bonnevie, $\mathrm{K}$.

1908. Chromosomenstudien. Arch. f. Zellf., I.

Boveri, Th.

1904. Ergebnisse uber die Konstitution der chroma-

Braun, Herm. tischen Substanz des Zellkerns, 1). 77 . Jena.

1909. Die spezifische Chronusomen/ahlen der tinheim. ischen Arten der Gattung $C$, rlops. Arch. $f$. Zellf., 3.

Buchner, Paul.

1909. Das accessorische Cliromosom in Spermatogenese und Ovogenese der Orthopteren, zugleich ein Beitrag zur Keuntniss der Recluktion. Arclı. f. Zellf., 3.

Byrnes, E. F.

1909. The Fresh-water Cyclops of L.ong Island. Bronklyn Inst. of Arts and Science.

Chambers, $R$.

1912. A Discussion of Cyclnps viridis Jurine. Binl.

Dublin, L., Bull., 22.

1905. The History of the Girm-cells of Pedicellina americasa. Ann. N. Y. Acad. Sc., I6.

Edward, C. L.

1911. The Sex Cluromosome in Ascaris felis. Arch. f. Zellf., 7 .

Farmer, J. B., and Moore, J. E. S.

1903. New Investigations into the Reduction Phenomenon of Animuls and Plants. l'roc. Roy. Soc., 72.

1905. On the Maiotic Phase in Aninıals and Plants. Quart. Journ. Micr. Sc., 48. 
Gates, R. R.

1911. The Mode of Chromosome Reduction. Bot. Gaz., Goldschmidt, $R$.

1908. Uber das Verhalten des Chromatins bei der Eireifung des Dicrocoelium ianceolatum. Arch.

Grigoire, V.

1904. La rér ion numérique des chromosomes et les cineses ne nuaturation. La cillule, 21.

1907. La formation des gemini hétérotypiques dans les Griggs, R. F. végétaux. La Cellule, 24.

1906. A Reducing D:vision in Ascaris megalocephala. Gruber, A. Ohio Nat., 1906.

1878. Die Buldung der Eisăckchen bei den Copepoden. Znol. Anz., Jahrg t.

1879. Beiträge zur Kenntniss der Generationsorgane der Hae.ker, $V$. freilebendrn Copepoden. Zeitsch. f. Wiss. Zool.

1895 a. Die Vorstadien der Eircifung. Arch. f. mikr.

1895 b. Uluer die Selbständigkeit der väterlichen und mutterlichen Kernbestandicile während der Em. bryonalentwicklung von Cyclops. Arch. f. mikr. Anat., 46.

1897. Die Keimbahn von Cyclops. Arch. f. mikr. Anat., 49.

1902. Uber das Schicksal der elterlichen und grosselterlichen Kernantcile. Jen. Zeitsch., 37.

1907. Dic Chromosomen als angenomnene Vererbungs. träger. Ergebn u. Fortschr. d. Zool., I.

19lo. Ergebnisse und Ausblicke uber dic Keimzellen. lorschung. Zeitsch. f. ind. Abst.-u. Vererbungs. lehre, 3 . 
Ishikawa, C.

1893. Studies on Reprodurtive Elemente, 1. Spermatogenesis, Oogencsis and Furtilization in Diap. tomus sp. Journ. of the Coll. of Sc.. Imp. Univ.

Janssens, F. A Jan., 5.

1901. La Spermatogéndse chezles Tiitons. La Cellule, 19. Jögensen, $M$

1910. Beitrage zur Kenntniss der Fihildung, Reifung, Befruchtung und Furchung hei Schwämmen (Syco.

Krimmel, $O$. nen). Arch. f. Zellf., 4 .

1910. Chromosomenverhăltnisse in gener.tiven und somatischen Mitosen bei Dioplomus coeruleus nebst Bemerkungen über die lintwicklung der Ge'sch.

Lerat, $\mathrm{P}$. lechtsorgane. Zool. Anz.. 35 .

1905. Les phencmènes de maturation dans l'ovogenèse et la spermatogenèse der Cyclops strenuus. La Cellule, 22.

McClung, C. E.

1905. Chromosome Complex of Orthopteran Sperna. Marcus, $H$. tocytes. Biol. Bull., 9.

1906. Ei und Samenreife bei Ascaris canis. Arch. f. nikr. Anat., $6 \%$.

Marsh, C. D.

1909. A Revision of the North American Species of Cyclops. Trans. Wiis. Arad. of Sc. Arts and Letters, 16.

Matschel, $\mathrm{H}$.

1910. ber Eireilung und Fiallage bei Copepoden. Arch. f. Zellf., 3.

Montgomery, T. H.

1903. The Huterotypic Maturation Mitosis in Am. phibia and Its General Significance. Biol. Bull., 4.

1904. Some Observations and Considerations upon the Maturation Phenomena of the Germ-Cills. Biol. Bılll., 6. 
1909. On Morphological Differences of the Chromosomes of Ascaris megalocephala. Arch. f. Zellf., 2.

1912. Complete Discharge of Mitochondria from the Oettinger, $\mathrm{R}$. Spermatozoon of Peripatus. Biol. Bull., 22.

1909. Zur Kenntniss der Spermatogenesc bei den MyriaRath, O. vom poden. Arch. f. Zellf., 3.

1895. Nene Beitrïgi zur Frage der Chromatinreduktion Rlickert, J. in der Samen und Eireife. Arch. f. nikr. Anat., 46.

: ó94. Zur Eireifung bei Copepoden. Anat. Hefte, 4.

Schiller, J.

1895. Zur Befruchtung von Cyclops strenuus. Anat. Anz., 10.

1908. Uber künstliche Hervorrufung von Vierergruppen be: Cyclops. Zool. Anz., 32

Schreiner, A. and 1:. E.

1904. Die Reifungsteilungen bei den Wirbeltieren. Anat. Anz., 24.

1906. Neue Studien liber die Chromatinreifung der Strasburgher, E. Geschlechtszellen. Arch. de Biol., 22.

1905. Typische und allotypische Kernteilung. Jahrb. Tretjakoff, $D$. f. wiss. Bot., 42.

1904 a. Die Bildung der Richtungskorper in den Eicrn von Ascaris megalocephala. Arch. f. mila. Anat., 65.

1904 b. Die Speımatogenese bei Ascaris megalocephala, Arch. f. mikr. Anat., 65.

Valle, Pietro della.

1909. L'organizzuzione della cromatina studiata medi. Wilson, E. $B$. ante ii numero dei cromosomi. Archivio Zool., 4.

1906. Studies on Cliromosr:ues, 111. The Sexual Differences of thr Curomosomes in Hemiptera. Jour.
Exp. Zrui., 3. 
Chambers: Chromosomfs in Cyclops

1909. Differences in the Chromosome- 11ps of Closely. $r^{\prime}$ 'ated Species and Varieties, $\epsilon^{+} \mathrm{C}$. Froc. Seventh I. rnat. Zool. Congress. Aug. 1907.

1911. Sturies on Chromosomes, VII. A Review of the Chromusomes of Nezara; With Some More

General Considerations. Jour. Morph., 22.

1905. Die Fortpflanzungsverhältnisse unserer einheimis. chen Copepoden. Zool. Jahrb. Syst., 22. 


\section{Explanation of Plates.}

All the figures, except Figs. 23 and 24, were drawn with a Zeiss $1.5 \mathrm{~mm}$. oil-immersion objective and a Zeiss No. 12 compensation ocular. For Fig. 23, ocular No. 8 was used; and for Fig. 24, ocular No. 6. The drawings were made with a Zeiss camera lucida at the level of the base of the microscope, and the reproductions are of the size of the originals.

Plate I.

Cyclops americanus.

FIG. 1. Oogonial equatorial plate, showing Io chromosomes. (Fixation, Flemming; stain, Heidenhain's iron haematoxylin).

Cyclops parcus.

2. Oogonial equatorial plate, showing 6 chromosomes. (Fl.; H.H.)

3. Polar view of oogonial anaphase daughter chromosomes. (Fl.; H.H.)

Cyclops Sp.

4. Nucleus of oviduct egg, late diakinesis showing 5 pairs of chromosomes. (Carnoy; H.H.)

Cyclops americanus.

5. Biserial arrangement of chromosomes in oviduct egg. A partial side view showing only 4 of the 5 paired chromosomes.

Cycloj's parcus.

6. Biserial arrangement. Polar view showing 3 paired chromosomes. (Sublimate alcohol (Braun); H.H.)

7. The same, showing smallest chromosome pair abnormally arranged. (Sbl. alc.: Delafield's haematoxylin.)

8. The same. End view of chromosomes.

9. The same. Latera! view of several chromosome pairs to show clear area when present is not always in middle of the chromosome rod. In $\mathrm{gb}$ one rod appears broken in the middle, the other remaining intact. (Sbl. alc.; Delaf. H.) 
Cyclops brevispinosus.

10. Biserial arrangement. The egg is lying in the latter end of the oviduct and is compressed from side to side, giving the cytoplasmic area about the chromosomes a spindle shape. There are two pairs of chroriosomes. (Carnoy; Delaf. H.)

11. Anaphase I in egg immediately after being laid. (Carnoy; Delaf. H.)

\section{Cyclops parcus.}

12. Anaphase I. (Sbl. alc.; H.H.)

(Sbl. alc.; H.H.)
(Sbl. alc.; H.H.)

13. Anaphase 1. (Sbl. alc.; H.H.)

\section{Plate 2.}

\section{Cyclops parcus.}

14. First polar body given off. The chromosomes in the egg are turning on their axes preparatory to the next aivision. (Sbl. alc.; H.H.)

15. Polar view in telophase I. (Picroformol; H.H.)

\section{Cyclops brevispinosus.}

16. Pular view in telophase I. (Carnoy; H.H.)

\section{Cyclops parcus.}

17. Metaphase II. (Picroformol; H.H.)

\section{Cyclops americanus.}

18. Metaphase I!. Only 4 of the 5 chromosomes are visible in the section of the egg nucleus. (Carnoy;
H.H.)

19. Chromosomes in metaphase II.

20. Telophase II. (Carnoy; safranin.)

21. Second polar body given off. Female pronucleus retreating in to egg. (Carnoy; H.H.)

\section{Cyclops parcus.}

22. Polar view of contiguous male and female pronuclei preparing for the first segmentation spindle. In one pronucleus the chromosomes are already splitting. (Camoy; H.H.) 
Plate 3.

SPERMATUuENLSIS IN Cyclops americanus.

(Fixation, strong Flemming; stain, Heidenhain'. iron haematoxylin).

\section{a. Keimpolster.}

23. Young Cyclops sp.? Keimpolster lying immediately under dorsal wall of cephalothorax.

24. Disintegrating Keimpolster at tip of adult testis. b. Multiplication Zone.

25. Resting spermatogonium.

26. Spermatogonial prophase, showing to chromosomes.

27. Spermatogonial metaphase.

28. Spermatogonial monaster showing to chromosomes.

29. Spermatogonial monaster taken from the end of the testis farthest from the Keimpolster.

c. Synizesis and Synapsis Zone.

30. Resting spermatogonium.

31. Network of spermatogonium forming into flaments and being drawn from nuclear wall.

32. Early synizesis figure.

33. Later synizesis figure.

34. Pachytene stage. Filaments lumpy along their
lengths.

35. Diplotene stage.

d. Early Diakinesis.

36. Five double chromatin filaments. The two filaments to the right extend out of the plane of the section and are therefore only partially shown.

37-38. The double chromatin filaments untwisting.

e. Late Diakinesis.

39. Two double filaments entirely untwisted. One is much contracted and thickened.

40. Definitely formed 5 double chromosomes of the spermatocyte of the first order.

41. The same. Abnormal in that the single elements of one of the pairs are separate. 
4. Maturation I.

42. Aateral view.

43. Chromosomes of metaphase I.

44. Late anaphase I. Polar view.

45. Telophase I.

g. Maturation II.

46. Spermatocyte of $t^{\circ}$ a second order.

47. Metaphase II.

48. Telophase II.

h. Spermiogenesis.

49. One spermatid with 5 chromosomes.

50. The same. Later stage.

51-54. Chromosomes being transformed into a hollow ball of chromatin network which becomes drawn out
into a spindle form.

55. Mature spermatozoon.

552. Transverse section of a mature spermatuzoon. 



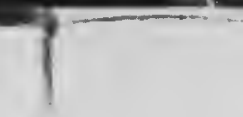

4. 
$3-n^{2}$

f 


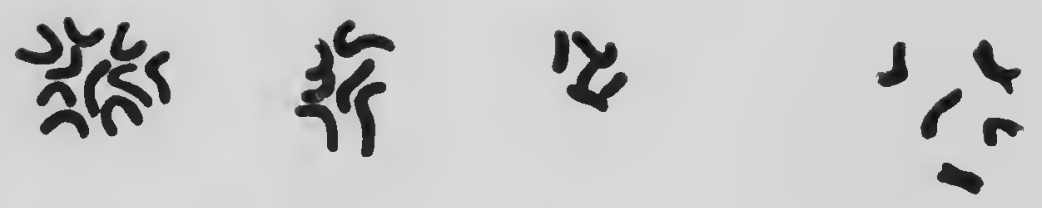
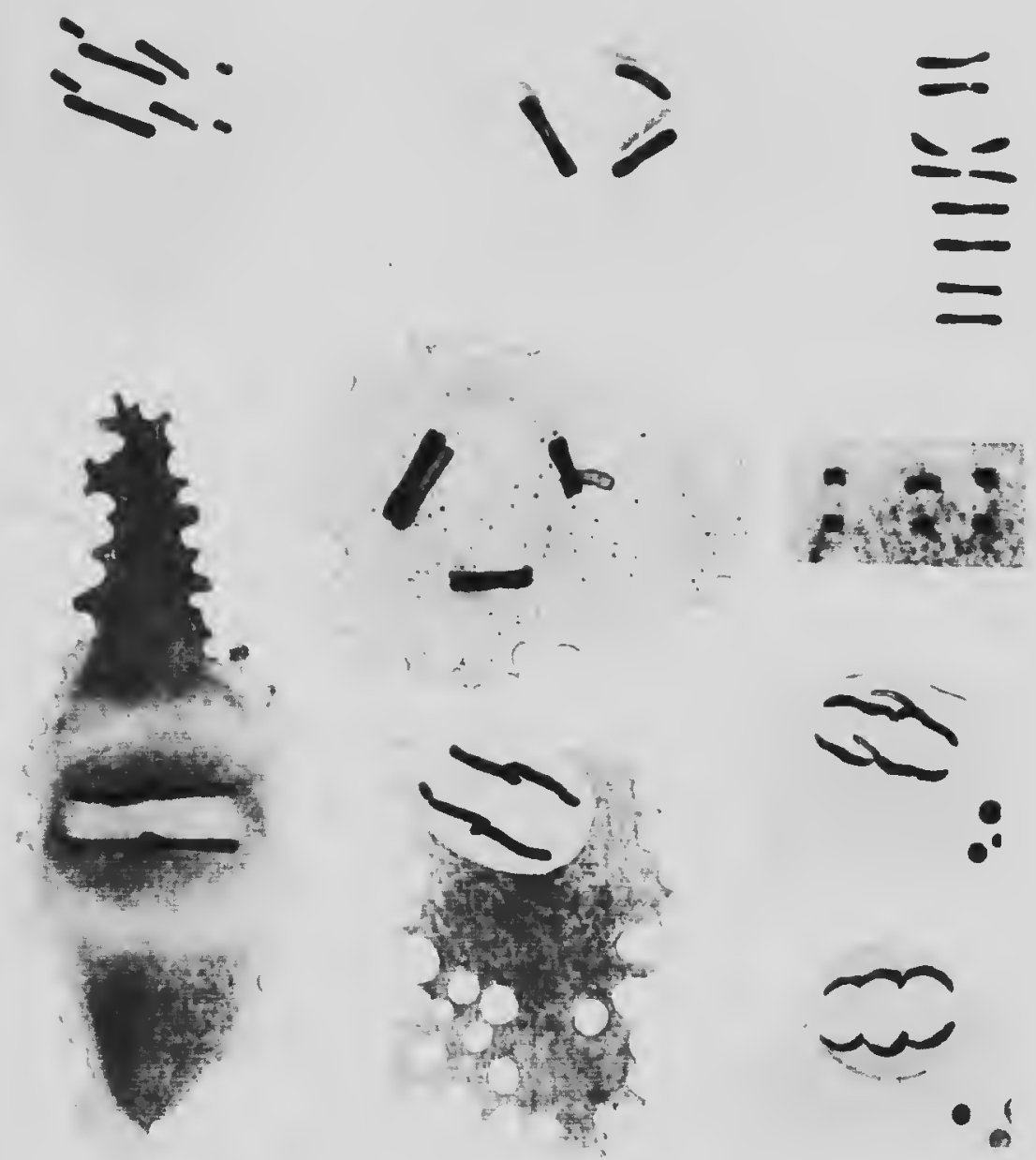
$p^{\prime-1+1}$ 

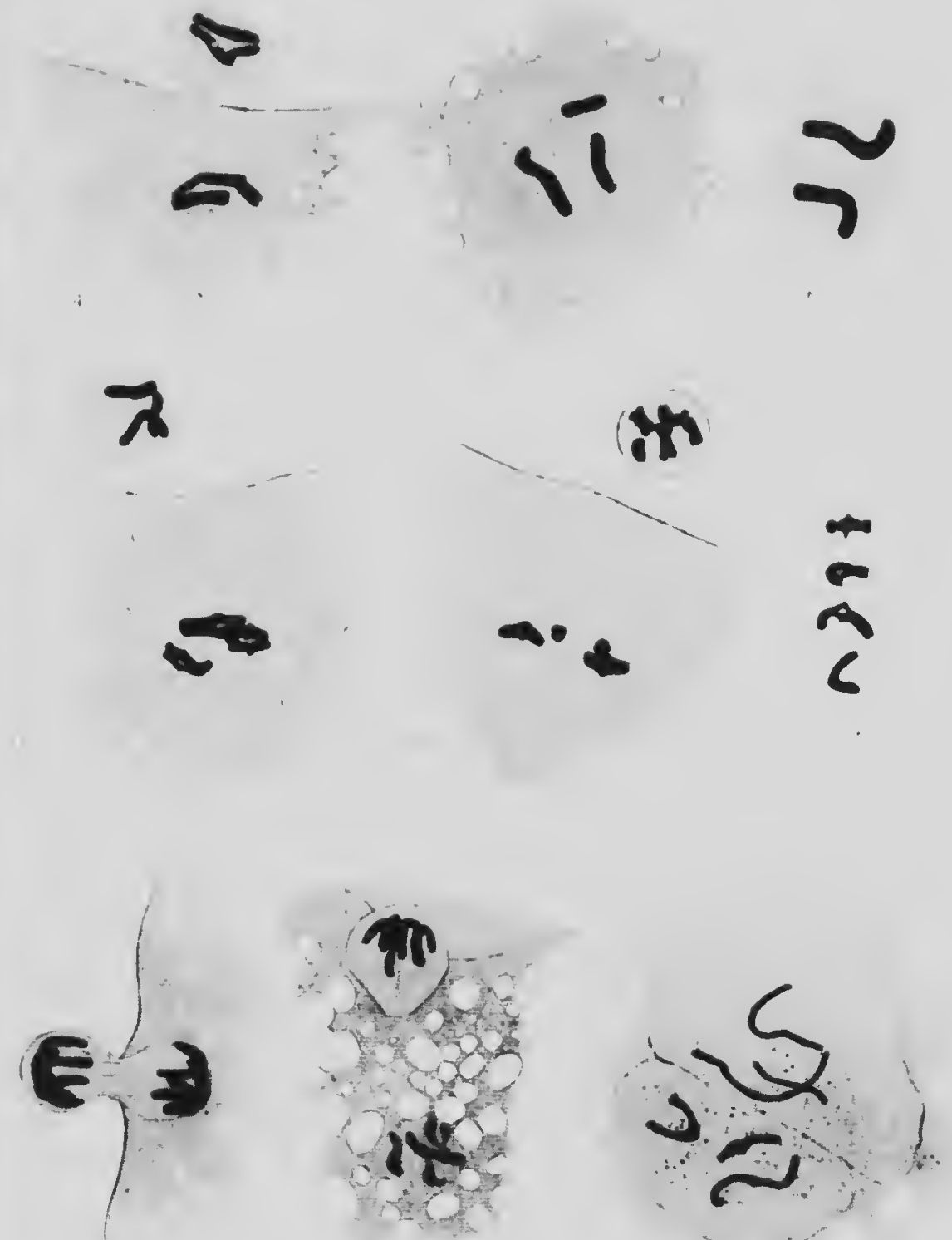
-194

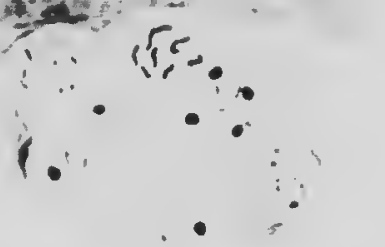

s)

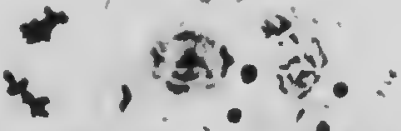

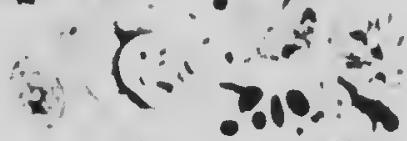

$$
\begin{aligned}
& \Rightarrow 1=0
\end{aligned}
$$

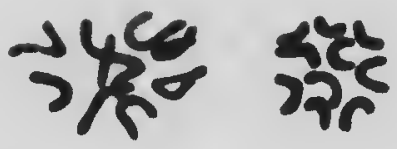

1)

सेखे

$\frac{2}{12}$

(y)

Eits $8=0$

13

12

18

市

is

4he 39

of w

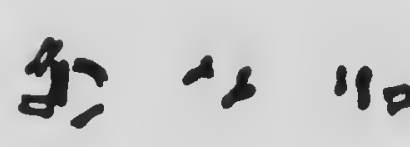

n

$y$

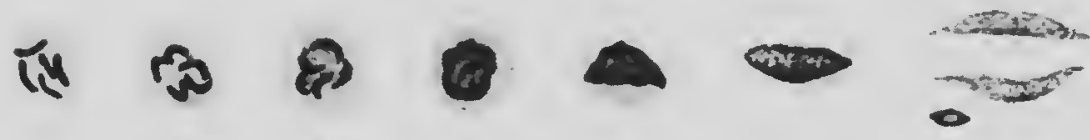




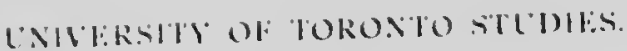

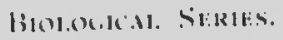

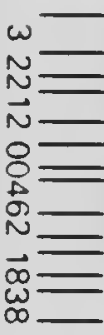

Do. 1: The gametophyte of listrychium Virginianum, by

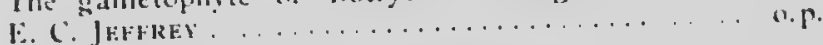

No, 2: The anatomy of the Osmundaceac, by J. H. FAll.1. . D.p.

Vo. i: (In the identification of Meckelian and mylohyovid srowses in the jaws of Mesozoic and recent manl-

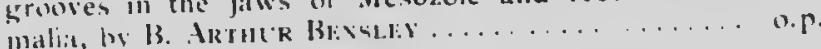

No. 4: The megaspore-membrine of the Gymnosperms, by R. B. THomsox .

No. 3: The homolugies of the stylar cusps in the upper molars of the Didelphyidae, by B. Akruth Brisisy 0.50

So. 6: On polystely in roots of Orchidaceae, by J. H. Wütk. ח. 5o

No. $;$ : In early Initdidymus of a chick, by R. Rims sy IVkilll 0.25

No. s: The habits and larval state of Plethrodon rirythronotus, by W. H. PIF.KaOC.

No. y: Spawn and larsa of Ambyotona Jeflersonianum, by IV. H. P'eknol. 0.25

No, a): The colour changes of uctopu andgaris l.mk., by E. $1^{\circ}$.

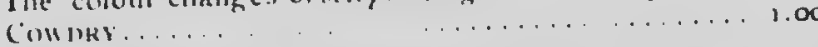

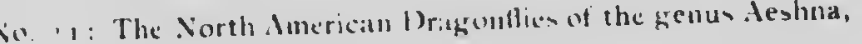

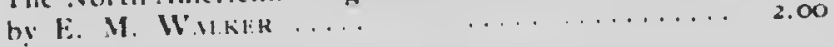

Vo, 12 : Ascidians from the coists of Camada, by $A$. (i.

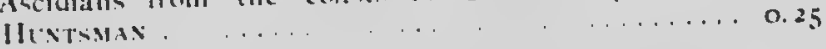

No. 13. A contribution to the morpholoky and biology of insect galls, by A. Cost:x........... $0.5^{\circ}$

lo. 11: liger maturation, dironosomes, and upermatogenesis

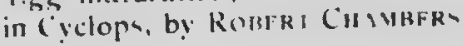




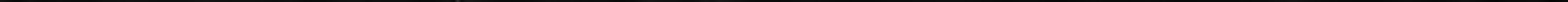

